\section{Nitrogen and Phosphorus Availability and Weed Suppression from Composted Poultry Litter Applied as Mulch in a Peach Orchard}

\author{
P.L. Preusch ${ }^{1}$ \\ Hood College, Frederick, MD 21701
}

\section{T.J. Tworkoski ${ }^{2}$ \\ U.S. Department of Agriculture, ARS, Appalachian Fruit Research Station, 45 Wiltshire Road, Kearneysville, WV 25430, and Hood College, Frederick, MD 21701

\begin{abstract}
Additional index words. ammonium, Mehlich 1-extractable phosphorus, nitrate, Prunus persica, organic, sustainable, water-extractable phosphorus, yield
\end{abstract}

\begin{abstract}
Composted poultry litter (CPL) may be applied as a mulch in fruit orchards to manage waste and to provide a slow-release nutrient source and weed control. With proper management, poultry manure and bedding (litter) can prevent environmental degradation, such as hypoxia in aquatic communities. Peach (Prunus persica L. 'Sunhigh') plots all received preemergence herbicides in May and then the following treatments in June 1998: commercial fertilizer $\left(\mathrm{N}\right.$ at $15 \mathrm{~g} \cdot \mathrm{m}^{-2}$ ), low rate CPL $\left(\mathrm{N}\right.$ at $15 \mathrm{~g} \cdot \mathrm{m}^{-2}$ as CPL at 2.9 $\mathrm{kg} \cdot \mathrm{m}^{-2}$ ), high rate CPL ( $\mathrm{N}$ at $62 \mathrm{~g} \cdot \mathrm{m}^{-2}$ as CPL at $11.6 \mathrm{~kg} \cdot \mathrm{m}^{-2}$ ), and no fertilizer or mulch control. Weeds were completely controlled by mulch and herbicide during 1998 but not during 1999. By Sept. 1999, the high rate of CPL had only $27 \%$ weed cover compared with $86 \%$ for the commercial fertilizer-treated plots. Soil $\mathrm{N}$ was highest $\left(\mathrm{NH}_{4}-\mathrm{N}\right.$ and $\mathrm{NO}_{3}-\mathrm{N}$ at 16.4 and $18.6 \mathrm{mg} \cdot \mathrm{kg}^{-1}$ soil, respectively) in plots treated with commercial fertilizer, 6 weeks after treatment (WAT). Soil $\mathbf{N}$ did not differ among the two CPL treatments and the control at any time. At the high rate of $\mathrm{CPL}$, there was $\mathrm{NH}_{4}-\mathrm{N}$ and $\mathrm{NO}_{3}-\mathrm{N}$ at 3.2 and $0.7 \mathrm{mg} \cdot \mathrm{kg}^{-1}$ soil, respectively, at 6 WAT. Water-extractable $P$ (WEP) in the soil did not differ among the CPL and commercial fertilizer treatments at 6 WAT (P at $\approx 14 \mathbf{~ m g} \cdot \mathrm{kg}^{-1}$ soil). However, at 47 WAT, plots with the high rate of CPL had significantly higher WEP, with $P$ at $30 \mathrm{mg} \cdot \mathrm{kg}^{-1}$ soil vs. $14 \mathrm{mg} \cdot \mathrm{kg}^{-1}$ soil in plots treated with commercial fertilizer. High applications of CPL could elevate $P$ in surface runoff to levels that cause environmental degradation. In general, Mehlich 1-extractable $\mathbf{P}$ (MEP) did not differ among the CPL- and fertilizer-treated plots (averaging $P$ at $45 \mathrm{mg} \cdot \mathrm{kg}^{-1}$ soil). MEP was lowest in control plots (averaging $P$ at $21 \mathrm{mg} \cdot \mathrm{kg}^{-1}$ soil). Results indicate that CPL could be used as a weed suppressant without adversely affecting $N$ release to the environment; however, $P$ concentration in soil water may be problematic.
\end{abstract}

Orchard floor management should integrate tactics to enhance fruit tree productivity and to protect natural resources. In peach orchards, weed management may include herbicides, tillage, and mulch (Tisdall, 1989). Herbicides and tillage effectively control weeds but resulting residues and reduced soil organic matter have decreased tree growth in replanted orchards (Tworkoski and Miller, 2001). In addition, herbicide availability and use could decrease due to the Food Quality Protection Act (1996) and to public resistance to agrochemicals.

There is renewed interest in mulching for weed suppression because organic materials, such as manure, are abundant and are perceived

Received for publication 1 May 2002. Accepted for publication 31 Dec. 2002.

${ }^{1}$ Current address: Univ. of Maryland Cooperative Extension, MD 4-H Center, 8020 Greenmead Dr., College Park, MD 20740-4000.

${ }^{2}$ To whom requests for reprints should be addressed. E-mail address: ttworkos@afrs.ars.usda.gov as safe by the public. Weeds were successfully controlled with organic mulches in California, which included use of woodchip waste in young pecan trees and composted poultry manure in an organic apple orchard (Smith et al., 2000; Swezey et al., 1998). Mulching crops with organic material such as poultry litter could help solve two problems of poultry farming and sustainable agriculture: proper disposal of waste, and weed control with reduced use of herbicides. About 13 million Mg of poultry litter and manure were produced in the United States in 1990, and the increasing amounts of this waste can not be disposed of in landfills or crops close to the site of origin (Eddy, 2000; Moore et al., 1998). Orchards that are managed with trees in weed-free strips and alternated with grass travel alleys may be well suited for mulch applications of composted manures. Composted manure mulch applied to weed-free strips could reduce use of synthetic herbicides and fertilizers, while surface runoff of nutrients may be reduced by the grass alleys if planted following land contours.

Organic mulches made with manures that are rich in nutrients may release significant quantities of nutrients if they are not managed properly (National Resource, Agriculture, and Engineering Service, 1999). Composting can reduce release of nutrients, such as $\mathrm{N}$, from organic mulch, and composted manures may release nutrients more slowly than synthetic fertilizers (Swezey et al., 1998). Managing $\mathrm{N}$ and $\mathrm{P}$ release from field applications of composted manures can be highly important because both $\mathrm{N}$ and $\mathrm{P}$ can contribute to eutrophication of freshwater and marine ecosystems (Laws, 1993). The objectives of this study were to determine the effect of poultry litter application as a mulch below peach trees on weed control, peach yield, and soil $\mathrm{N}$ and $\mathrm{P}$ concentrations.

\section{Materials and Methods}

Peach trees ('Sunhigh' on 'Lovell' rootstock) were planted in Mar. 1988 in Hagerstown silt loam (fine, mixed semiactive mesic Typic Hapludalf) using a $5 \times 5 \mathrm{~m}$ spacing near Kearneysville, W.Va. Trees were pruned to an open center each winter. Trees were not irrigated or thinned during the experiment but pests were managed based on regional recommendations (Pfeiffer, 1998). A 3-m-wide weed-free strip was maintained beneath the trees with $1 \mathrm{~kg} \cdot \mathrm{ha}^{-1}$ diuron [ $N^{\prime}$-(3,4-dichlorophenyl)$N, N$-dimethylurea] and $1 \mathrm{~kg} \cdot \mathrm{ha}^{-1}$ terbacil [5-chloro-3-(1,1-dimethylethyl)-6-methyl2,4(1H,3H)-pyrimidinedione] applied each May until 1998. The following four treatments were applied on 23 June 1998 to $3 \times 5$ m plots: commercial fertilizer $\left(\mathrm{N}\right.$ at $15 \mathrm{~g} \cdot \mathrm{m}^{-2}$ as $10 \mathrm{~N}-4.4 \mathrm{P}-8.3 \mathrm{~K}$ at $0.015 \mathrm{~kg} \cdot \mathrm{m}^{-2}$ ); low rate composted poultry litter (CPL) application (N at $15 \mathrm{~g} \cdot \mathrm{m}^{-2}$ as CPL at $2.9 \mathrm{~kg} \cdot \mathrm{m}^{-2}$ to a depth of $\approx 3$ $\mathrm{cm}$ ); high rate CPL application ( $\mathrm{N}$ at $62 \mathrm{~g} \cdot \mathrm{m}^{-2}$ as CPL at $11.6 \mathrm{~kg} \cdot \mathrm{m}^{-2}$ to a depth of $\approx 10 \mathrm{~cm}$ ); and no fertilizer or CPL (control). The low rate of application was the equivalent of $\mathrm{N}$ and $\mathrm{P}$ at 150 and $86 \mathrm{~kg} \cdot \mathrm{ha}^{-1}$, respectively. The high rate of CPL was equivalent to $\mathrm{N}$ and $\mathrm{P}$ at 601 and $343 \mathrm{~kg} \cdot \mathrm{ha}^{-1}$, respectively. Herbicides were not used after treatments were applied.

The CPL was obtained from the Potomac Valley Conservation Facility in Moorefield, W.Va. At this facility, mixtures of fresh turkey (Meleagris gallopavo) and chicken (Gallus gallus domesticus) (broiler) litters were combined with hardwood chips to adjust the $\mathrm{C}: \mathrm{N}$ ratio to 60:1. This mixture was kept under a roofed structure in windrows that were turned and mixed for aeration once a week. The moisture level in the mixture was maintained at $50 \%$ (on a dry weight basis) for 3 months by adding water as necessary.

Soil N and P, weed abundance, and peach leaf N were measured during 1998 and 1999. Soil samples in the peach orchard were collected with a 2.5 -cm-diameter soil probe at three random places from 0 - to $10-\mathrm{cm}$ depth beneath each tree at $6,10,47$, and 63 weeks after treatment (WAT). Care was used not to include CPL in the sample. The three samples per plot were pooled and stored frozen until analysis for $\mathrm{NH}_{4}-\mathrm{N}, \mathrm{NO}_{3}-\mathrm{N}$, water-extractable phosphorus (WEP), and Mehlich 1-extractable 
phosphorus (MEP). Two P assays were used to evaluate potential environmentally labile $\mathrm{P}$ (WEP) and plant available P (MEP).

Soil $\mathrm{N}$ was measured by shaking $5 \mathrm{~g}$ soil with $40 \mathrm{~mL} 2 \mathrm{~m} \mathrm{KCL}$ for $1 \mathrm{~h}$ (Keeney and Nelson, 1982). Following centrifugation, the supernatant was removed and analyzed colorimetrically with a Bran and Luebbe autoanalyzer (Buffalo Grove, Ill.). Ammonium and nitrate were measured by the method of Markus et al. (1985). Plant-available soil P (MEP) was measured by shaking $5 \mathrm{~g}$ of soil with $20 \mathrm{~mL} 0.05 \mathrm{M} \mathrm{HCL}$ and $0.025 \mathrm{M} \mathrm{H}_{2} \mathrm{SO}_{4}$ for 5 min (Mehlich 1953). The suspensions then were centrifuged for $15 \mathrm{~min}$ (3500 rpm) and filtered (Whatman 42, Whatman International Ltd., Maidstone, England). Water-extractable phosphorus was measured by shaking $1 \mathrm{~g}$ soil extracted with $25 \mathrm{~mL}$ water for $1 \mathrm{~h}$. The suspensions were centrifuged at $3500 \mathrm{rpm}$ and filtered through $0.45-\mu \mathrm{m}$ nylon filters. Phosphorus in the supernatant was measured as ortho $\mathrm{PO}_{4}$ with a Bran and Luebbe Autoanalyzer by Method 696 B-82W (Olson and Sommers, 1982; Tan, 1996).

Leaf $\mathrm{N}$ concentration was measured in composite samples of 30 peach leaves collected from each tree during the 1998 and 1999 growing seasons. Leaves were dried at $60{ }^{\circ} \mathrm{C}$, ground to pass a $2-\mathrm{mm}$ sieve, and $\mathrm{N}$ concentration was determined with a Nitrogen Determinator (LECO Corp., Model FP-228, St. Joseph, Mich.)

Weed control was estimated visually by two people as the percent ground area covered by weeds beneath each tree each month during the 1998 and 1999 growing seasons. The most prevalent weeds were nodding chickweed (Stellaria longifolia Muhl.), yellow sweet clover [Melilotus officinalis (L.) Lam.], and white clover (Trifolium repens L.). Other weeds included: Virginia pepperweed (Lepidiun virginicum L.), red deadnettle (Lamium purpureum L.), yellow woodsorrel (Oxalis stricta L.), field hawkweed (Hieracium pratense Tausch.), lambsquarter (Chenopodium album L.), red clover (Trifolium pratense L.), orchardgrass (Dactylis glomerata L.), bindweed (Convolvulus arvensis L.), daisy fleabane (Erigeron strigosus Muhl.), lady's thumb (Polygonum persicaria L.), and wild grape (Vitus vulpina L.). Number and weight of peach fruit were measured with one picking when most fruit had yellowish-green ground color on 22 July 1998 and 3 Aug. 1999.

The design of the experiment was a randomized complete block with single tree experimental units and five replications, for a total of 20 experimental units. Each experimental unit consisted of a $3 \times 10 \mathrm{~m}$ plot beneath one tree. Treatment effects were evaluated by analysis of variance and means were separated using the Bonferroni (Dunn) $t$ test (SAS Institute, 1991).

\section{Results and Discussion}

Nitrogen. At 6 WAT, soil treated with commercial fertilizer had at least $4 \times$ more $\mathrm{NH}_{4}-\mathrm{N}$ and $16 \times$ more $\mathrm{NO}_{3}-\mathrm{N}$ than $\mathrm{CPL}$-treated soil (Table 1). By 10 WAT, both $\mathrm{NH}_{4}-\mathrm{N}$ and $\mathrm{NO}_{3}$ -
$\mathrm{N}$ concentrations decreased by $\approx 50 \%$ in soil treated with commercial fertilizer. At 47 WAT, $\mathrm{NH}_{4}-\mathrm{N}$ was not detected and $\mathrm{NO}_{3}-\mathrm{N}$ did not differ between plots receiving CPL, commercial fertilizer, and control. Soil $\mathrm{NH}_{4}-\mathrm{N}$ and $\mathrm{NO}_{3}-\mathrm{N}$ concentrations were the same in control and CPL-treated plots at each sampling time. Therefore, CPL contributed little or no sustained inorganic $\mathrm{N}$ to soil when it was applied as a mulch.

In a related mineralization study where the same CPL was mixed with the same soil found in the orchard in the current study, the CPL $\mathrm{N}$ mineralization rates were low, in the range of $5 \%$ to $8 \%$ over 16 weeks (Preusch, 2000; Preusch et al., 2002). Mineralization of organic $\mathrm{N}$ from other composted manures was $\approx 4 \%$ in 16 weeks (Hartz et al., 2000). The low soil $\mathrm{N}$ found in the current experiment was thus probably due to low mineralization rates, $\mathrm{N}$ immobilization into organic matter, and $\mathrm{N}$ uptake by the tree. In addition, substantial $\mathrm{NH}_{3}$ volatilization has been found when poultry litter was applied to soil surface (Carreker et al., 1973). These findings may not apply in all systems, since $\mathrm{N}$ availability in organic agricultural practices varies with soils, climate, and crops (Clark et al., 1999).

Hartz et al. (2000) found low N mineralization rates in composts and suggested that long-term, repeated applications of composts might be necessary to increase soil N. Kraus et al. (2000) proposed that supplemental fertilizer $\mathrm{N}$ may be needed for container-grown plants amended with composted turkey litter. In another report, Kraus and Warren (2000) found that composted turkey litter released adequate $\mathrm{P}$ but not $\mathrm{N}$ for container-grown plant production. Based on our work discussed below, Pavailability should be considered with $\mathrm{N}$ mineralization when CPL is used for nutrient management in a fruit orchard.

Peach leaf $\mathrm{N}$ concentration was highest in commercial fertilizer treatments until 47 WAT, when there was no difference among all treatments (Table 2). Leaf $\mathrm{N}$ in the CPL-treated trees was higher than control at only 6 WAT. This result may have been due to a high release of $\mathrm{NH}_{4}-\mathrm{N}$ within 4 weeks of application that was seen in a related mineralization experiment (Preusch et al., 2002), which would not have been detected at the 6 WAT soil sampling time used in the current experiment.

Phosphorus. Water-extractable $\mathrm{P}$ in the peach orchard soil samples did not differ among the CPL and fertilizer treatments at 6 WAT; however, at 47 WAT, the high rate of CPL application yielded $\mathrm{P}$ at $30 \mathrm{mg} \cdot \mathrm{g}^{-1}$ soil compared with $\mathrm{P}$ at $14 \mathrm{mg} \cdot \mathrm{g}^{-1}$ soil in commercial fertilizer treatments (Table 3 ). There was a CPL rate effect at 47 and 63 WAT with WEP from the low rate of CPL being about half of the WEP from the high rate of CPL. It is possible that high WEP from CPL mulch may lead to greater Pin surface runoff and have adverse environmental consequences, such as accelerated eutrophication of lakes (Pote et al., 1996). However, runoff was not measured, and grass-covered travel alleys adjacent to mulchtreated plots may reduce $\mathrm{P}$ loss.

Mehlich 1-extractable $\mathrm{P}$ was greatest at 47 WAT (P at $55.3 \mu \mathrm{g} \cdot \mathrm{g}^{-1}$ soil) in plots treated with

Table 1. Ammonium $\left(\mathrm{NH}_{4}-\mathrm{N}\right)$ and nitrate $\left(\mathrm{NO}_{3}-\mathrm{N}\right)$ in soil collected at $6,10,47$, and 63 weeks after composted poultry litter (CPL) mulch application in June 1998 beneath 'Sunhigh' peach trees.

\begin{tabular}{|c|c|c|c|c|}
\hline \multirow[b]{2}{*}{ Treatment } & \multicolumn{4}{|c|}{ Weeks after CPL application } \\
\hline & 6 & 10 & 47 & 63 \\
\hline & \multicolumn{4}{|c|}{$\mathrm{NH}_{4}\left(\mathrm{~N}\right.$ at $\mathrm{mg} \cdot \mathrm{g}^{-1}$ soil $)$} \\
\hline Commercial fertilizer & $16.4 \mathrm{a}^{\mathrm{z}}$ & $7.2 \mathrm{a}$ & $\mathrm{nd}^{y}$ & nd \\
\hline CPL-low rate & $3.9 \mathrm{~b}$ & $4.8 \mathrm{~b}$ & nd & nd \\
\hline CPL-high rate & $3.2 \mathrm{~b}$ & $4.2 \mathrm{~b}$ & nd & nd \\
\hline \multirow[t]{2}{*}{ Control } & $2.9 \mathrm{~b}$ & $4.1 \mathrm{~b}$ & nd & nd \\
\hline & \multicolumn{4}{|c|}{$\mathrm{NO}_{3}\left(\mathrm{~N}\right.$ at $\left.\mathrm{mg} \cdot \mathrm{g}^{-1} \mathrm{soil}\right)$} \\
\hline Commercial fertilizer & $18.6 \mathrm{a}$ & $9.5 \mathrm{a}$ & $0.42 \mathrm{a}$ & nd \\
\hline CPL-low rate & $1.1 \mathrm{~b}$ & $0.5 \mathrm{~b}$ & $0.26 \mathrm{a}$ & nd \\
\hline CPL-high rate & $0.7 \mathrm{~b}$ & $0.5 \mathrm{~b}$ & $0.49 \mathrm{a}$ & nd \\
\hline Control & $1.0 \mathrm{~b}$ & $0.5 \mathrm{~b}$ & $0.31 \mathrm{a}$ & nd \\
\hline
\end{tabular}

${ }^{2}$ Within each form of nitrogen and column, means followed by the same letter do not differ at $P \leq 0.05$. ${ }^{\mathrm{y}}$ nd $=$ not detected.

Table 2. Peach leaf $\mathrm{N}$ concentration at 6,10 , and 47 weeks after composted poultry litter (CPL) mulch application in June 1998 beneath 'Sunhigh' peach trees.

\begin{tabular}{lccc}
\hline & \multicolumn{3}{c}{ Weeks after CPL application } \\
\cline { 2 - 4 } Treatment & 6 & 10 & 47 \\
\hline & Leaf- $N$ & $\left(N\right.$ at mg $^{-1} g^{-1}$ & leaf $)$ \\
Commercial fertilizer & $31 \mathrm{a}^{\mathrm{z}}$ & $28 \mathrm{a}$ & $27 \mathrm{a}$ \\
CPL-low rate & $26 \mathrm{~b}$ & $23 \mathrm{~b}$ & $25 \mathrm{a}$ \\
CPL-high rate & $26 \mathrm{~b}$ & $24 \mathrm{~b}$ & $27 \mathrm{a}$ \\
Control & $23 \mathrm{c}$ & $22 \mathrm{~b}$ & $25 \mathrm{a}$ \\
\hline
\end{tabular}

${ }^{2}$ Within each column, means followed by the same letter do not differ at $P \leq 0.05$. 
Soll Management, Fertilization, \& Irrigation

the high rate of CPL (Table 3). There was no CPL rate effect on MEP extracted from soil. Soil mulched with CPL sometimes had substantially higher WEP and MEP than control soil. Therefore, CPL may contribute significant $\mathrm{P}$ to soil when it is applied as a mulch. In previous research, composted chicken manure increased soil $\mathrm{P}$ concentration but did not affect soil $\mathrm{NO}_{3}$ and $\mathrm{NH}_{4}$ concentrations when applied to organic apple orchards in Colorado (Davis et al. 2001). Swezey et al. (1998) found higher leaf P concentrations in apple trees that were mulched with poultry litter than in unmulched trees. We did not measure leaf $\mathrm{P}$ concentration, but enhanced $\mathrm{P}$ uptake might be expected by peach trees receiving high rates of CPL.

Weed abundance. Weeds were completely controlled in all treatments during 1998, probably due to the early-season herbicide application (data not shown). In 1999, the low rate CPL-treated plots and control plots had high weed abundance similar to the commercial fertilizer plots (Table 4). Weed abundance was reduced by the high rate of CPL. These results are similar to Swezey et al. (1998), who found mulched orchards suppressed weed growth. In the current experiment, weeds were emerging through the mulch applied at the high rate by the end of the 1999 growing season, so the suppression effect may be temporary.

Weeds that grew through the high rate of CPL were robust and would likely require management in addition to the CPL mulch. These results are similar to those of Niggli et al. (1990), who found that litter compost did not provide adequate weed control in an apple orchard, but did improve soil organic matter and reduce $\mathrm{N}$ in the soil solution, compared with bare soil. An organic mulch groundcover in an orchard can interfere with weed growth by changing soil surface conditions, but it may also promote weed growth by providing nutrients to weeds that emerge through the mulch. In the current experiment, the high rate of CPL suppressed weeds through the second season after application. Herbicide or mechanical control could be included during the third season.

Peach yield. In 1998, the number and weight of fruit in the size class $>5.7 \mathrm{~cm}$ were not affected by treatments (averaging 276 fruit in this size class per tree, with a weight of $38 \mathrm{~kg}$ per tree) (Table 5). In 1999, the number and weight of fruit in the size class $>5.7 \mathrm{~cm}$ again were not affected by treatments (averaging 244 fruit in this size class per tree, with a weight of $45 \mathrm{~kg}$ per tree). This suggests that soil nutrient levels were sufficient to sustain yield, that weeds were not interfering with growth, and that mulching with CPL did not adversely affect or improve limiting soil nutrients and yield. The sufficiency range for peach tree $\mathrm{N}$ concentration in the mid-Atlantic region is $2.50 \%$ to $3.40 \%$ nitrogen (Crasswell and Greene 1995). Peach leaf nitrogen was near this range for all treatments. Swezey et al. (1998) found that mulching apple trees with composted poultry manure did not control weeds as well as herbicidal weed management but, as in this study, yield was not reduced by weed

Table 3. Water-extractable P (WEP) and Mehlich 1-extractable P (MEP) in soil collected at $6,10,47$, and 63 weeks after composted poultry litter (CPL) mulch application in June 1998 beneath 'Sunhigh' peach trees.

\begin{tabular}{lcccc}
\hline & \multicolumn{4}{c}{ Weeks after CPL application } \\
\cline { 2 - 5 } Treatment & 6 & 10 & 47 & 63 \\
\hline & \multicolumn{4}{c}{$W E P\left(m g\right.$ P $g^{-1}$ soil $)$} \\
Commercial fertilizer & $15.7 \mathrm{a}^{2}$ & $8.7 \mathrm{a}$ & $14.4 \mathrm{~b}$ & $5.9 \mathrm{bc}$ \\
CPL-low rate & $15.1 \mathrm{a}$ & $15.2 \mathrm{a}$ & $15.7 \mathrm{~b}$ & $12.1 \mathrm{~b}$ \\
CPL-high rate & $12.1 \mathrm{ab}$ & $17.2 \mathrm{a}$ & $30.4 \mathrm{a}$ & $23.2 \mathrm{a}$ \\
Control & $6.8 \mathrm{~b}$ & $5.6 \mathrm{~b}$ & $8.5 \mathrm{~b}$ & $0.2 \mathrm{c}$ \\
& \multicolumn{5}{c}{$M E P\left(m g\right.$ P g $\left.^{-1} \mathrm{soil}\right)$} \\
Commercial fertilizer & $60.8 \mathrm{a}$ & $45.4 \mathrm{a}$ & $46.4 \mathrm{ab}$ & $21.5 \mathrm{bc}$ \\
CPL-low rate & $42.3 \mathrm{a}$ & $54.7 \mathrm{a}$ & $36.3 \mathrm{ab}$ & $39.6 \mathrm{a}$ \\
CPL-high rate & $24.3 \mathrm{a}$ & $46.0 \mathrm{a}$ & $55.3 \mathrm{a}$ & $33.1 \mathrm{ab}$ \\
Control & $18.4 \mathrm{a}$ & $19.6 \mathrm{~b}$ & $24.7 \mathrm{~b}$ & $14.9 \mathrm{c}$ \\
\hline
\end{tabular}

${ }^{2}$ Within each form of phosphorus and column, means followed by the same letter do not differ at $P \leq 0.05$.

Table 4. Weed abundance during 1999 at 50, 54, 58, 62, and 64 weeks after composted poultry litter (CPL) mulch application in June 1998 beneath 'Sunhigh' peach trees.

\begin{tabular}{lccccc}
\hline & \multicolumn{5}{c}{ Weeks after CPL application } \\
\cline { 2 - 6 } Treatment & 50 & 54 & 58 & 62 & 64 \\
\hline \multirow{5}{*}{ Cround area covered (\%) } \\
CPL-low rate & $30 \mathrm{a}^{\mathrm{z}}$ & $40 \mathrm{a}$ & $53 \mathrm{a}$ & $81 \mathrm{a}$ & $86 \mathrm{a}$ \\
CPL-high rate & $34 \mathrm{a}$ & $23 \mathrm{ab}$ & $35 \mathrm{a}$ & $55 \mathrm{~b}$ & $61 \mathrm{a}$ \\
Control & $2 \mathrm{~b}$ & $9 \mathrm{~b}$ & $10 \mathrm{~b}$ & $23 \mathrm{c}$ & $27 \mathrm{~b}$ \\
\hline
\end{tabular}

${ }^{2}$ Within each column, means followed by the same letter do not differ at $P \leq 0.05$.

Table 5. Yield in 1998 and 1999 after composted poultry litter (CPL) mulch application in June 1998 beneath 'Sunhigh' peach trees.

\begin{tabular}{lrrrc}
\hline \multirow{2}{*}{ Treatment } & \multicolumn{3}{c}{ Fruit diam $\leq 5.7 \mathrm{~cm}$} & \multicolumn{2}{c}{ Fruit diam $>5.7 \mathrm{~cm}$} \\
\cline { 2 - 5 } & No. & Wt $(\mathrm{kg})$ & No. & Wt $(\mathrm{kg})$ \\
\hline Commercial fertilizer & $298 \mathrm{a}^{\mathrm{z}}$ & $24 \mathrm{a}$ & $262 \mathrm{a}$ & $36 \mathrm{a}$ \\
CPL-low rate & $279 \mathrm{a}$ & $23 \mathrm{a}$ & $267 \mathrm{a}$ & $36 \mathrm{a}$ \\
CPL-high rate & $297 \mathrm{a}$ & $24 \mathrm{a}$ & $270 \mathrm{a}$ & $38 \mathrm{a}$ \\
Control & $257 \mathrm{a}$ & $22 \mathrm{a}$ & $304 \mathrm{a}$ & $40 \mathrm{a}$ \\
& \multicolumn{4}{c}{1999} \\
Commercial fertilizer & $9 \mathrm{a}$ & $1 \mathrm{a}$ & $239 \mathrm{a}$ & $48 \mathrm{a}$ \\
CPL-low rate & $12 \mathrm{a}$ & $1 \mathrm{a}$ & $229 \mathrm{a}$ & $41 \mathrm{a}$ \\
CPL-high rate & $6 \mathrm{a}$ & $1 \mathrm{a}$ & $241 \mathrm{a}$ & $47 \mathrm{a}$ \\
Control & $12 \mathrm{a}$ & $1 \mathrm{a}$ & $264 \mathrm{a}$ & $44 \mathrm{a}$ \\
\hline${ }^{2}$ Within each year and column, means followed by the same letter do \\
not differ at $P \leq 0.05$.
\end{tabular}

competition in the organically managed trees. Our yield and fruit weight results were similar to a study in Fresno County, Calif., in which there was no significant difference in peach tree yield for eight treatments of different manures and composts that were disked into the soil in a peach orchard (Andris et al., 1997). In any orchard, it is likely that weed competition could reduce yield if edaphic resources like $\mathrm{N}$ or water were to drop to levels insufficient for fruit production.

During the first year of this experiment, soil $\mathrm{N}$ and peach leaf $\mathrm{N}$ concentration was lower in the CPL than in the commercial fertilizer treatments. During the second year after treatment, soil $\mathrm{N}$ had decreased in all treatments and only the higher rate of CPL provided weed control. Although yield was the same for all treatments, it is likely that additional $\mathrm{N}$ fertilizer and weed suppression would be necessary to ensure peach tree yield. More or larger applications of CPL could be used but the WEP from high rates of
CPL can increase with time, suggesting that $P$ from CPL could be in runoff. This work demonstrated that CPL can be applied as mulch to suppress weeds and provide $\mathrm{N}$ but release of $\mathrm{P}$, and possibly other nutrients, should be more clearly elucidated.

\section{Literature Cited}

Andris, H.L., R.S. Johnson, K.M. Daane, T. Michailides, D.H. Crisosto, and T. Prather. 1997. A comparative analysis of soil amendments used in peach production, p. 4-7. In: State of California Integrated Waste Mgt. Board, Publ. No. 422-96-051, Compost Demonstration Proj., Fresno County.

Carreker, J.R., S.R. Wilkinson, J.E. Box, R.N. Dawson, E.R. Beaty, H.D. Morris, and J.B. Jones. 1973. Using poultry litter, irrigation, and tall fescue for no-till corn production. J. Environ. Qual. 2:497-500.

Clark, M.S., W.R. Horwath, C. Shennan, K.M. Scow, W.T. Lanini, and H. Ferris. 1999. Nitrogen, weeds 
and water as yield-limiting factors in conventional, low-input, and organic tomato systems. Agr., Ecosyst., and Environ. 73:257-270.

Crasswell, R.M. and G.M. Greene II. 1995. Nutrition, p.175-183. In: H.W. Hogmire (ed.). Mid-Atlantic orchard monitoring guide. Northeast Reg. Agr. Eng. Serv., Ithaca, N.Y., NRAES-75.

Davis, J.G., R.J. Zimmerman, and A.G. Gaus. 2001. Nutrient availability for apple trees from chicken manure and compost, p. 15. In: First Natl. Organic Tree Fruit Res. Symp., Grand Junction, Colo.

Eddy, D. 2000. Waste not, want not. Compost isn't just for backyard growers any more as both organic consumption and pressure to recycle green waste increase, p. 11-14. Fruit Grower.

Hartz, T.K., J.P. Mitchell, and C. Giannini. 2000. Nitrogen and carbon mineralization dynamics of manures and composts. HortScience 35: 209-212.

Keeney, D.R. and D.W. Nelson. 1982. Nitrogeninorganic forms, p. 643-698. In:A.L.Page(ed.). Methods of soil analysis, Part 2. Chemical and microbiological properties. Agron. Monogr. No. 9. ASA-SSA, Madison, Wis.

Kraus, H.T., R.L. Mikkelsen, and S.L. Warren. 2000. Container substrate temperatures affect mineralization of composts. HortScience 35: 16-18.

Kraus, H.T. and S.L. Warren. 2000. Performance of turkey litter compost as a slow-release fertilizer in containerized plant production. HortScience 35:19-21.

Laws, E.A. 1993. Aquatic pollution. Wiley, New York.

Markus, D.K., J.P. McKinnen, and A.F. Baccafuri. 1985. Automated analysis of nitrite, nitrate, and ammonium nitrogen in soils. Soil Sci. Amer. J. 49:1208-1215.

Mehlich, A. 1953. Determination of P, Ca, Mg, K, $\mathrm{Na}$ and $\mathrm{NH}_{4}-\mathrm{N}$. Soil Testing Div. Publ. 1-53, North Carolina Dept. Agr., Raleigh.

Moore, P.A., T.C. Daniel, A.N. Sharpley, and C.W. Wood. 1998. Poultry manure management, $\mathrm{p}$. 60-77. In: R.J. Wright, W.D. Kemper, P.D. Millner, J.F. Power, and R.F. Korcak (eds.). Agricultural uses of municipal, animal, and industrial byproducts. U.S. Dept. Agr. Conservation Res. Rpt. 44.

National Resource, Agriculture, and Engineering Service. 1999. Compost utilization on the farm, p. 85-97. In: M. Dougherty (ed.). Field guide to on-farm composting. Natl. Resource, Agr. and Eng. Serv. (NRAES). Publ. No. 114.

Niggli, U., F.P. Weibel, and W. Gut. 1990. Weed control with organic mulch materials in orchards. Integrated fruit production. Acta Hort. 285:97-102.

Olson, S.R. and L.E. Sommers. 1982. Phosphorus, p. 403-429. In: A.L. Page (ed.). Methods of soil analysis, Part 2. Chemical and microbiological properties. Agron. Monogr. No. 9 (2nd ed.). Amer. Soc. Agron. and Soil Sci. Soc. Amer., Madison, Wis.

Parish, S. 1990. A review of non-chemical weed control. Biol. Agr. Hort. 7:117-137.

Pfeiffer, D.G. (bul. coordinator). 1998. Virginia-West Virginia-Maryland commercial tree fruit spray bulletin. Virginia Coop. Ext. Publ. 456-419.

Pote, D.H, T.C. Daniel, A.N. Sharpley, P.A. Moore, D.R. Edwards, and D.J. Nichols. 1996. Relating extractable soil phosphorus to phosphorus losses in runoff. Soil Sci. Soc. Amer. J. 60: 855-859.
Power, J.F. and J.W. Duran. 1984. Nitrogen use in organic farming, p. 585-598. In: R.D. Hauck (ed.). Nitrogen in crop production. Amer. Soc. Agron., Madison, Wis.

Preusch, P.L. 2000. Nitrogen mineralization rates and phosphorus availability of composted and uncomposted poultry litter. MS Thesis, Biology Dept., Hood College, Frederick, Md.

Preusch, P.L., P.R. Adler, L.J. Sikora, and T.J. Tworkoski. 2002. Nitrogen mineralization rates and phosphorus availability in composted and uncomposted poultry litter. J. Environ. Qual. 31:2051-2057.

Robinson, J.B. 1989. Strategies of fertilizer use in perennial fruit crops. Austral. Temperate Fruits Rev. Conf. Acta Hort. 240:169-176.

SAS Institute. 1985. SAS user's guide: Statistics. Vers. 5 ed. SAS Inst., Cary, N.C.

Smith, M.W., B.L. Carroll, and B.S. Cheary. 2000. Mulch improves pecan tree growth during orchard establishment. HortScience 35:192-195.

Swezey, S.L., M.R. Werner, M. Buchanan, and J. Allison. 1998. Comparison of conventional and organic apple production systems during three years of conversion to organic management in coastal California. Amer. J. Alt. Agr. 13:162-180.

Tan, K.H. 1996. Determination of macroelements p. 135-170. In: Soil sampling, preparation and analysis. Marcel Dekker. New York.

Tworkoski, T. and S. Miller. 2001. Apple and peach orchard establishment following multi-year use of diuron, simazine, and terbacil. HortScience 36:1211-1213.

Tisdall, J.M. 1989. Soil management. Austral. Temperate Fruits Rev. Conf. Acta Hort. 240: 161-168. 